\title{
Educate, Empower And Protect People Through Timely Authentic Information: Explore How Bangladeshi Newspapers Response To COVID-19 Pandemic
}

https://doi.org/10.21272/sec.4(2).93-103.2020.

Pryanka Dutta, ORCID: https://orcid.org/0000-0002-6493-7041

MSS Researcher, Department of Journalism \& Media Studies, Jahangirnagar University, Bangladesh

Urme Dutta, ORCID: https://orcid.org/0000-0003-1689-2018

Undergraduate Student, Department of Psychology, University of Dhaka, Bangladesh

Sanaulla Hasan, ORCID: https://orcid.org/0000-0002-7992-629X

Lecturer, Department of Journalism and Media Studies, Port City International University, Bangladesh

Nandita Sarkar, ORCID: https://orcid.org/0000-0002-0397-544X

BSS Researcher, Department of Journalism \& Media Studies, Jahangirnagar University, Bangladesh

Tanmoy Sana, ORCID: https://orcid.org/0000-0001-5199-8331

MPH, M. Pharm, Global Centre for Environmental Remediation (GCER), The University of Newcastle, Callaghan, Australia

\begin{abstract}
This study analyzed the coverage of the coronavirus disease of 2019 (COVID-19) news by three prominent Bangladeshi dailies named The Daily Star, The Daily Kalerkantho, and The Daily Ittefaq. The research aimed to explore the attention cycle of the selected newspapers about this ongoing outbreak. It also identified the significant differences in framing and used sources in the news stories by respective daily newspapers. The study period was 10 weeks from February 1 to April 10, 2020, considering the Global Health Emergency declaration by the World Health Organization on January 30, 2020, and the announcement of the pandemic on March 11,2020. This research applied the content analysis method on 761 news articles. The study shows that these three newspapers gave more attention after the pandemic announcement. This study also revealed that The Daily Star emphasized on attributing responsibility to the government and statistical data frames. On the other hand, The Daily Kalerkantho highlighted the individual's responsibility frame. The Daily Ittefaq concentrated on the economic consequence frame. Regarding the news sources, The Daily Star significantly used more sources from government officials. In contrast, The Daily Kalerkantho relied more on experts, and The Daily Ittefaq frequently used international sources. Due to time limitations, this study only covered the early stage of COVID-19 in Bangladesh. So more samples with a more extended period might clearly illustrate the focus of print media regarding this pandemic. Journalism and media studies students, academicians, and journalists will be most beneficiaries of this study. As appropriate framing helps to build awareness and indepth knowledge of the community as well as policymakers, print media should pay more attention to proper framing.
\end{abstract}

Keywords: Bangladesh, COVID-19, newspaper coverage, news framing, news source, pandemic, print media.

JEL Classification: I1, L8.

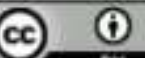

This work is licensed under a Creative Commons Attribution 4.0 International License.

Cite as: Dutta, P., Dutta, U., Hasan, S., Sarkar, S., Sana, T. (2020). Educate, Empower And Protect People Through Timely Authentic Information: Explore How Bangladeshi Newspapers Response To COVID-19 Pandemic. SocioEconomic Challenges, 4(3), 93-103. https://doi.org/10.21272/sec.4(2).93-103.2020.

(C) The Authors, 2020. This article is published with open access at Sumy State University. 


\section{Introduction}

The word 'Pandemic' often not heard. When a new disease outbreak cross international boundaries and spread worldwide by affecting a large population, then it called pandemic (Last et al., 2001). Human history had experienced pandemic several times. COVID-19 outbreak in 2019-20 is the latest pandemic that first appeared in Wuhan, Hubei province, China in December 2019 (Gralinski and Menachery, 2020). In early December 2019, patients were admitted to the hospital with a mystery virus. The local doctor suspected that the virus originated in the Wuhan Seafood Market (Liu et al., 2020). On January 9, 2020, The Wall Street Journal unveiled the outbreak of coronavirus, which was acknowledged by The Chinese Center for Disease Control and Prevention (CDC) (Gralinski and Menachery, 2020). Initially, the Chinese government locked down the province and imposed travel restrictions to block the spread. However, it was too late to stop the outbreak. Gradually South Korea, Japan, Iran, Italy, Spain became the epicenters of COVID-19 (McKibbin and Fernando, 2020). At the time of writing this paper USA, Brazil and Russia were new epicenters.

WHO stated COVID-19 as the pandemic on March 11, 2020. Previously, on January 30, 2020, the WHO avowed coronavirus as a global emergency. January to March within this short time, super spreader COVID19 spread across the globe. As of June 30, 2020, about 10,302,052 cases have been confirmed and 505,505 deaths in 188 Countries (JHCRC, 2020). Worldwide doctors and health care workers have been struggling to tackle this crisis. Scientists are trying their best to invent a vaccine against this disease (Tanne et al., 2020). Many countries like the USA, UK, Italy, Spain, Iran, Singapore, and India chose the lockdown option. For stopping transmission, people were urged to stay at home.

The economic impact of this crisis is devastating. Industries like retail, hospitality, food, service, and entertainment closed their operations (Mogaji, 2020). The U.S. Private Sector Job Quality Index recommended that nearly $37 \mathrm{M}$ jobs could be lost worldwide due to the coronavirus pandemic (MarketWatch, 2020). Because of the drop in demand, worldwide oil price collapses very dramatically (BBC, 2020b). To bounce back, most of the countries' governments announced stimulus packages to boost their economy (Mogaji, 2020). Antonio Guterres, United Nations Secretary-General, considered this ongoing COVID-19 pandemic as the worst global crisis after the $2^{\text {nd }}$ World War. The global economy will face a recession that it had not been experienced in the recent past (BBC, 2020a).

World Health Organization (WHO) continually suggested countries to test and isolate each case of COVID19 but the scarcity of testing kits, poor healthcare infrastructure make it impossible for many nations (Boseley, 2020). The country like Bangladesh, which is one of the world's most densely populated nations now facing lots of challenges to block the community transmission. The Healthcare system of Bangladesh is not well prepared to tackle this current pandemic; for instance, Bangladesh has a minimal number of Intensive Care Unit (ICU) beds to combat the COVID-19 patients' influx (Mostafa, 2018). The initial three COVID-19 cases in Bangladesh were identified on March 8, 2020. Among them, two men were returned from Italy and another woman was an infected person's contacted family member (The Daily Star, 2020). On March 18, 2020, the Institute of Epidemiology, Disease Control and Research (IEDCR) confirmed the first death caused by COVID-19 in Bangladesh (SUJAN, 2020). At the time of writing this paper, as of June 30, 2020, about 141,801 cases have been confirmed and over 1,783 deaths in Bangladesh (IEDCR, 2020).

To halt the community transmission, the Bangladesh government took some effective actions like the lockdown of some vulnerable areas, banning flights, shutting down educational institutions, and encouraging people to practice social distancing and staying at home (Mahmud, 2020). Although there was some criticism like the government should take these actions earlier and the scarcity of personal protective equipment (PPE), testing kits, masks, and goggles would not be severe if authority realized the gravity of the crisis (MOLLA, 2020).

At this crisis moment as the fourth estate, Bangladeshi newspapers have a significant duty in disseminating information, creating awareness, and evaluate government actions to fight against the invisible enemy. Mass communication researchers agreed that media representation on any issues could shape public perception (Lee and Paik, 2017; Hasan and Dutta, 2019). In this pandemic situation, it could be more relevant as COVID-19 is a new phenomenon and directly connected to public safety. This study aimed to explore as a developing country, how Bangladeshi newspapers responded to this COVID-19 pandemic. Precisely, the purpose of the study was to find out the noteworthy variances of framing and used sources in news stories by The Daily Star, 
The Daily Kalerkantho, and The Daily Ittefaq. It also scrutinized the attention cycle of the selected newspapers about this ongoing outbreak.

\section{Literature review}

The disease called COVID-19, caused by Severe Acute Respiratory Syndrome Coronavirus 2 (SARS-CoV2), already been traveled to 188 countries across the globe (JHCRC, 2020). Commonly appearing COVID-19 symptoms are cough, breathing difficulties, and fever, but in severe condition may cause the severe acute respiratory syndrome, pneumonia, and death. The incubation period of COVID-19 for revealing the symptoms is 2-14 days. Now, COVID-19 is spreading community levels from person to person by contacting the infected person or secretions, cough, or sneeze (Heymann and Shindo, 2020).

The outbreak got extensive media attention, and gradually it became the top news with alarming spread across the world. As mentioned before, several studies proved that media has an influential role in shaping public perceptions regarding which issues are significant by highlighting specific features (McCombs, 2018). For instance, in the case of the COVID-19 pandemic, the media will inform the public: what is the latest situation, how to tackle it, what is the government responsibilities, what is the individual's duty, how affected people will get proper health care access and so on. From media representation, people will also understand the depth of the issue (Seale, 2003; Kee et al., 2010).

How media coverage influences public opinion and attitude? To answer this question media researcher identified two significant processes: agenda-setting and framing (Kee et al., 2010). Mass media agenda-setting theory posited that the media set the public sphere by stressing some issues than other issues (McCombs, 2002). Framing is considered as another active process of media influence. According to Entman, news framing plays a vital impact in interpreting social problems and make it prominent to the audience. Selection and more salience communication about any issue and promotion of a particular narration, moral judgment, and solution illustrate the critical aspects of framing (Entman, 1993).

News framing navigates the audience by explaining 'how to think about an issue' (Nelson and Kinder, 1996). Audience understanding and interpretation of a social problem mostly depend on the way that a news story is framed (de Vreese et al., 2011). Especially in a crisis where the urgent decision needs to take, media framing plays a significant role for public and political elites (Berinsky and Kinder, 2006; Boin et al., 2009). The major contributing factors in the crisis period lay in how the media frame it and certain entities' responsibilities and actions (Lee and Paik, 2017).

Luther \& Zhou (2005) analyzed SARS news frames in the United States and China, where they found both countries' newspapers used responsibility, human interest, economic consequence, conflict, and leadership frames (Luther and Zhou, 2005). Another research on SARS and Chinese media coverage demonstrated that Chinese national dailies highlighted the health severity frame; whereas, the economic frame was frequently employed by the Chinese web portal (Hong, 2007).

Kee et al. (2010) studied Malaysian print media framing on the H1N1 pandemic where government responsibility frame was heavily used frame among Malaysian papers which indicated that all newspapers urged the government to solve the crisis (Kee et al., 2010). Another study on the H1N1 outbreak scrutinized the U.S. news articles mostly employed action, attribution of responsibility, and reassurance frame than Korean news (Jung Oh et al., 2012). The Times of India covered the H1N1 pandemic as a war. They focused on six news frames named: severity, fear and panic, scientific information, attribution of responsibility, safety, and human interest frames (Gadekar et al., 2014).

In 2012, another pandemic occurred named Middle East Respiratory Syndrome (MERS). A study conducted on MERS coverage in South Korean newspapers concluded that government responsibility was highlighted by left-wing dailies in contrast, right-wing dailies stressed on individual responsibility frame (Lee and Paik, 2017). After analyzing health crisis like SARS, H1N1, and MARS, journalism and media studies scholars identified some common frames that media used frequently (Bardhan, 2001; Beaudoin, 2007; Gadekar et al., 2014; Jung Oh et al., 2012; Luther and Zhou, 2005; Wu, 2006) though, the use of this frame may differ in the country to country (Jung Oh et al., 2012). All the frames are discussed as follows-

Attribution of responsibility frame: When one issue considered as a crisis, attributing responsibility to certain entities seemed like a critical concern. Responsible bodies for the crisis as well as resolution are disclosed in 
the attribution of responsibility frame (Entman, 1993; Iyengar, 1991). People's perception of the crisis like a disease outbreak directly linked with how media discussed certain entities' accountability (Mastin et al., 2007). When the media are attributing responsibility to the government or authorities, public assess the crisis as complex and structural landed. In contrast, if media are assigning the responsibility of the individual, which results in dramatization, de-contextualization, and personalization of the crisis and it will lead the citizen to minimize the gravity of the crisis (Bennett, 2016; Iyengar, 1996).

Human interest frame: This frame tells about the problem by illustrating the individual or group of individual feelings or emotions. All stories that belong to the human interest frame focused on the human emotional angle (Semetko and Valkenburg, 2000).

Reassurance frame: What action already been taken by authority or government to handle the disease is emphasized on the reassurance frame (Shih et al., 2008). This frame helps to alleviate public panic (Lee and Paik, 2017).

Economic consequence: The economic consequence frame shows in what ways and how a pandemic impact on national and international economic structure and what will be the future consequences (Semetko and Valkenburg, 2000).

New evidence: New information about the disease such as how it spread, how to tackle it, what drug should be used discussed in new evidence frame. This frame exclusively suitable for a pandemic condition (Jung Oh et al., 2012).

Statistical frame: In this frame, the seriousness of the pandemic narrates statistically like describe how many people infected and died at a particular time. Here media could not use any journalistic interpretation (Jung Oh et al., 2012).

Affected regions frame: This frame focused on the place of disease outbreak, epicenters, and worldwide scenario.

Uncertainty frame: The severity and uncertainty about the outbreak are discussed in the uncertainty frame. Sometimes media used this frame in such a way that escalate public fare and panic (Jung Oh et al., 2012).

\section{News source}

News source is one of the potent textual tools in the news frame (Pan and Kosicki, 1993). Who is quoted in the news story, considered as a source for that particular news (Sundar, 1998). As Entman (1993) pointed out that, public cognition about the issue also influenced by source quotation and identity (Entman, 1993; Lasorsa and Reese, 1990). Previous studies indicated that media houses mostly rely on 'government officials' as an authentic source (Schudson, 2002). However, there is an argument that government officials advocate forthe government (Schudson, 2002). In a crisis, journalists also depend on expert opinion. Experts explain the situation and show the solutions as well as future consequences (Conrad, 1999; Steele, 1995). Therefore, after analyzing several studies on newspapers coverage of pandemics, we also used other sources like; laypeople (person who have no expert knowledge but observed or experienced COVID-19), international sources (international organizations or sources from overseas), and politicians (Jung Oh et al., 2012; Lee and Paik, 2017) for content analysis.

\section{Research questions}

After scrutinizing previous studies regarding newspapers coverage on pandemics, the researchers constructed research questions as follows:

During the study period, how was the attention cycle of the three selected newspapers (The Daily Star, The Daily Kalerkantho, and The Daily Ittefaq) about COVID-19 news?

Whether there would be any difference in framing COVID-19 news articles by the respective newspapers?

$>\quad$ What are the variations among cited sources?

\section{Methodology}

\section{Sampling}

The content analysis of COVID-19 news stories was performed conducted by utilizing three Bangladeshi dailies named The Daily Star, The Daily Kalerkantho, and The Daily Ittefaq. These three prominent mainstream dailies were considered due to their circulation and social impact. The Daily Kalerkantho and The 
Daily Ittefaq are the two most influential Bengali dailies and The Daily Star is a popular English newspaper in Bangladesh. The study period was ten weeks from February 01 to April 10, 2020, considering the World Health Organization's declaration of Global Health Emergency on January 30, 2020, and the announcement of the pandemic on March 11, 2020. Content analysis was confined to the front page. We have chosen the front page because of the most important news displayed on the newspaper's front page (Zhang and Fleming, 2005). In this study, single news was considered as an analyzing unit. For collecting articles from three selected papers, we used their archived option where they displayed their digital copy of printed newspapers. Among a total of 761 articles, The Daily Star comprises 249 articles, The Daily Kalerkantho 280 articles, and The Daily Ittefaq 232 articles. For framing analysis, we have excluded 36 articles as these articles did not fit in selected frames.

\section{Coding procedure}

The authors analyzed all articles from the sample. We often found that some stories have more than one frame, at this circumstance following the previous study on pandemic and print media, we have selected a dominant frame as the principal organizing feature of the news (Entman et al., 2009). The lead paragraph of the article was considered as the dominant frame (Jung Oh et al., 2012).

\section{Data analysis}

For analyzing data, SPSS 25.0 software (IBM SPSS, Armonk, NY, USA) was used to perform the Chi-square test to find the association between variables.

\section{Result and Discussions}

\section{Attention cycle}

A total of 761 news stories was identified throughout this research period. Data presented in Figure-1 indicated that after WHO announced the pandemic of COVID-19 on March 11, 2020, newspapers' coverage on this issue was dramatically increased. However, on January 30, 2020, WHO alarmed these diseases as a Global Health Emergency, selected newspapers' coverage was on average during the Global Health Emergency period (February 01 to March 06, 2020), the first five weeks of the study. This Global Health Emergency period could be considered as preparation time for the outbreak. The second phase of the study started from March 07 to April 10, 2020; these five weeks were during the pandemic period. Bangladesh's first death caused by COVID19 also happened during this time frame. Therefore, in this phase, the number of COVID-19 patients was increasing at an alarming rate. At this stage, selected newspapers' front pages were entirely focused on COVID-19 issues, internal or external news on the front page was somehow related to this outbreak.

\begin{tabular}{|c|c|c|c|c|c|c|c|c|c|c|}
\hline & \\
\hline
\end{tabular}

Figure 1. News articles according to the week from February 01 to April 10, 2020 (10 weeks) 
Table 1. News articles according to newspapers

\begin{tabular}{|l|c|c|}
\hline \multicolumn{1}{|c|}{ Newspaper } & Frequency & Percentage (\%) \\
\hline The Daily Star & 249 & 32.7 \\
\hline The Daily Kalerkantho & 280 & 36.8 \\
\hline The Daily Ittefaq & 232 & 30.5 \\
\hline Total Sample & 761 & 100 \\
\hline
\end{tabular}

Source: Researcher's field data.

In terms of daily newspapers, The Daily Kalerkantho contributed the most units with 280 counts or $36.8 \%$ among all news (Table 1). It followed by The Daily Star (249 units or 32.7\%) and The Daily Ittefaq (232 units or $30.5 \%$ ). These data revealed that during this study period, The Daily Kalerkantho paid more attention to these issues in contrast to The Daily Star and The Daily Ittefaq.

Framing the news stories

Table 2. Various types of news frames used in three prominent Bangladeshi newspapers

\begin{tabular}{|c|c|c|c|c|c|c|c|}
\hline Frames & \multicolumn{2}{|c|}{ The Daily Star } & \multicolumn{2}{|c|}{ The Daily Kalerkantho } & \multicolumn{2}{|c|}{ The Daily Ittefaq } & Test \\
\hline & $\mathrm{N}$ & $\%$ & $\mathrm{~N}$ & $\%$ & $\mathrm{~N}$ & $\%$ & \multirow{11}{*}{$\begin{array}{l}\text { Chi-square }=90 \\
d f=81 \\
p=0.231\end{array}$} \\
\hline New evidence & 5 & 2.0 & 9 & 3.4 & 5 & 2.3 & \\
\hline Attribution of govt. responsibility & 63 & 25.4 & 51 & 19.5 & 36 & 16.7 & \\
\hline Human interest & 19 & 7.7 & 16 & 6.1 & 11 & 5.1 & \\
\hline Reassurance & 48 & 19.4 & 56 & 21.5 & 47 & 21.8 & \\
\hline Economic consequence & 16 & 6.5 & 12 & 4.6 & 23 & 10.6 & \\
\hline Statistical Data & 42 & 16.9 & 30 & 11.5 & 22 & 10.2 & \\
\hline Uncertainty & 4 & 1.6 & 1 & 0.4 & 1 & 0.5 & \\
\hline Affected regions & 43 & 17.3 & 43 & 16.5 & 52 & 24.1 & \\
\hline Individual's responsibility & 8 & 3.2 & 43 & 16.5 & 19 & 8.8 & \\
\hline Total & 248 & & 261 & & 216 & & \\
\hline
\end{tabular}

Source: Researcher's field data.

The second research question served whether there would be any difference in framing COVID-19 articles by respective daily newspapers. As illustrated in Table-2, The Daily Star emphasized on the attribution of government responsibility frame $(25.4 \%)$, followed by reassurance $(19.3 \%)$ and statistical data $(16.9 \%)$ frames. In Kalerkantho, the reassurance frame seemed most frequent $(21.5 \%)$ followed by government responsibility (19.5\%) and individual responsibility (16.5\%). In The Daily Ittefaq news coverage, the affected regions frame was highly used (24.1\%), followed by reassurance (21.8\%) and economic consequence (10.6\%) frames.

Data shows that significant differences existed in news frames used by three dailies. For instance, The Daily Star emphasized on attributing responsibility to the government. The newspaper wrote a headline on February 5, 2020, "Measures at airport still found wanting" another news like that "Screening still lax at Dhaka airport" (The Daily Star, March 10, 2020). Both stories described that international airport safety measures need to increase, the screening process should be vigorous and incoming passengers from the highly infected countries must be isolated for 14 days.

"Virus can cause havoc in Rohingya camps" (The Daily Star, March 18, 2020), in this news The Daily Star warned the government about the Rohingya refugee camp's safety. If coronavirus spreads in the southern region where more than a million Rohingya refugees settled, it would be devastating. The Daily Star continuously scrutinized government actions. A headline on March 19, 2020, "Govt now scrambles for testing kits, PPE, Experts slam failure to act timely" where they narrated the scarcity of testing kits and personal protective equipment (PPE) would not be severe if the government act timely. Another report reads "Govt should ramp up contact tracing" (The Daily Star, March 21, 2020) suggested that the Bangladesh government should take more initiatives to trace and quarantine suspected cases. "Tests too few to rule out possibility" (The Daily Star, March 23, 2020) described that the government needs to run more tests around the country to unveil the actual scenario of virus transmission. Because of lockdown, thousands of marginalized people became jobless. "HELPING THE POOR, Govt needs to do more, faster say experts as authorities prepare list of those in dire need of food aid, other support amid coronavirus fallout" (The Daily Star, March 28, 2020) with this report Daily star urge government immediate action to help those marginalized people. 
Here more examples that attributed government responsibility frame: "Import 1,000 ventilators immediately" (The Daily Star, March 31, 2020), "Low test rate may be belying reality" (The Daily Star, April 01, 2020), "Govt to help affected SMEs; Move designed to protect the industries that employ 2.45 Cr people" (The Daily Star, April 02, 2020), "Enforce total LOCKDOWN, Experts urge govt as new infections, deaths surge; track the hidden cases" (The Daily Star, April 09, 2020).

The Daily Star also emphasized on statistical data frame compared to The Daily Kalerkantho and The Daily Ittefaq which indicated that this daily was trying to highlight the seriousness of the COVID-19 by showing the increasing number of patients in a statistical manner. During this study period most of the day, The Daily star used a box in its front page, named "update" where they displayed the increasing cases in Bangladesh along with total world cases. Therefore, compare to other dailies, this newspaper also used more human interest frame.

The Daily Kalerkantho, which is a prominent and one of the highest circulated dailies in Bangla language focused on the Reassurance frame. They discussed government efforts to handle this crisis. A headline reads "Bangladeshe china der on arrival visa sthogit" (The Daily Kalerkantho, February 03, 2020) trans: Bangladesh Government temporarily stops on arrival visa facilities for all Chinese citizens". Another headline reads "Deshe tin joner corona sonakto, Muib Barsar March 17 parade Ground ar mul onusthan sthogit" (The Daily Kalerkantho, March 09, 2020) trans: Bangladesh recorded its first three coronavirus cases, the government postponed the key event of March 17, 2020, at National Parade Ground in Dhaka planned for mega $100^{\text {th }}$ birthday celebration of Sheikh Mujibur Rahman (Father of the Nation). "Corona mokabelay 12 te bisesaeto hospital prostut" (The Daily Kalerkantho, March 22, 2020) trans: government prepared 12 specialized hospitals to tackle corona. To halt the community transmission government also imposed a nationwide lockdown and implement penalties. Here two headlines about this decision: "Aj theke sob bondho. $4^{\text {th }}$ April porjonto manush ke ghore rakher sorbatok prostuti" (The Daily Kalerkantho, March 26, 2020) trans: from March 26 to April 4, 2020, government-imposed countrywide lockdown; all public transport should be banned. "Corona rodhe nirdesona na manle sasthi" (The Daily Kalerkantho, March 26, 2020) trans: penalties should be applied if break the rules aimed to stop coronavirus. Another headline on April 06 "72750 koti taka pronodona" (The Daily Kalerkantho, April 6, 2020) trans: To support the economy of Bangladesh, the government announced Tk 72,750.00 billion stimulus package.

Compare to other dailies, The Daily Kalerkantho significantly used individual responsibility frame that may reflect individuals could protect themselves by taking some actions to avoid this disease. Washing hands frequently, covering cough, maintaining social distance, staying at home are some steps that individuals can follow to stop or slow the spread of the virus. The Daily Kalerkantho discussed these messages with graphics. Here some headlines from this frame: "Barbar dhorte hoy amon jinish porisker rakhun" (The Daily Kalerkantho, March 11, 2020) trans: clean everything that you frequently use." Koromordon noy, baire barole basi sotorkota" (The Daily Kalerkantho, March 18, 2020) trans: No handshake; more careful when going outside. "Ghore thakun nijer jono onoder jono" (The Daily Kalerkantho, April 18, 2020) trans: for yourself and others safety, please stay at home.

The Daily Ittefaq continually illustrated world scenarios using the affected regions frame. For instance, on February 15, 2020, a headline read "Coronavirus: bishhay akranto 64 hajar" (The Daily Ittefaq, February 15, 2020) trans: globally 64,000 people were affected by the coronavirus. "Mask songkot bishho jure" (The Daily Ittefaq, March 3, 2020) trans: face mask shortage across the globe. "Sobche basi akranter talikay Juktorastro tritio" (The Daily Ittefaq, March 24, 2020) trans: the USA was the third among most affected countries in the world. "Bisshojure mritu 46 hajar chariyeche" (The Daily Ittefaq, April 2, 2020) trans: worldwide COVID-19 death toll crossed 46,000.

The Daily Ittefaq also concentrated on the Economic Consequence frame. Global rescission and its impact on Bangladesh, upcoming socio-economic consequences elaborately discussed here. Some headlines from this frame: "2008 saler monda ke o chariye jate pare coronar provab" (The Daily Ittefaq, February 29, 2020) trans: Coronavirus rescission will severe than 2008 rescission. "Corona atongke sharebazar e potoner record" (The Daily Ittefaq, March 10, 2020) trans: Dhaka stock exchange faced massive fall because of corona fear. "Chottogram bondore containerer stup" (The Daily Ittefaq, April 1, 2020) trans: containers congestion on Chattogram port. 
There was a commonality in three newspapers that the uncertainty frame was almost absent in their news article. Another previous study conducted by Jung et al. (2012) claimed a similar scenario that if official organizations like WHO provide accurate and precise information to journalists, then it will be easy to avoid dramatic uncertainty frame which creates fear and panic among the public (Jung Oh et al., 2012).

\section{News Sources}

The third research question explored the differences among the used sources of COVID-19 articles among selected daily newspapers. According to Table-3, in The Daily Star, the maximum quoted sources were the government (36.7\%), followed by international (27.3\%), laypeople (18.9\%), and experts $(16.8 \%)$. In The Daily Kalerkantho, the highly mentioned sources were the government $(37.4 \%)$ following international (25.9\%), experts (22.3\%), laypeople (14.3\%). On the other hand, The Daily Ittefaq most cited sources were international (37.9\%), the government (33.9\%), experts (17.8\%), laypeople $(10.1 \%)$. There were some similarities and differences in how three respective dailies used sources. One similarity was that all selected newspapers highly relied on government sources. Therefore, selected dailies rarely used politicians as a source, which indicated that regarding COVID-19 newspapers did not pay much attenuation to politician's voices.

Table 3. Cited sources in respective dailies

\begin{tabular}{|c|c|c|c|c|c|c|c|}
\hline Source & \multicolumn{2}{|c|}{ The Daily Star } & \multicolumn{2}{|c|}{ The Daily Kalerkantho } & \multicolumn{2}{|c|}{ The Daily Ittefaq } & Test \\
\hline Government & 374 & 36.7 & 319 & 37.4 & 187 & 33.9 & \multirow{6}{*}{$\begin{array}{l}\text { Chi-square }=30 \\
d f=25 \\
p=0.224\end{array}$} \\
\hline Experts & 171 & 16.8 & 190 & 22.2 & 98 & 17.8 & \\
\hline Politicians & 3 & 0.3 & 2 & 0.2 & 2 & 0.4 & \\
\hline Laypeople & 192 & 18.9 & 122 & 14.3 & 56 & 10.1 & \\
\hline International & 278 & 27.3 & 221 & 25.9 & 209 & 37.9 & \\
\hline Total & 1018 & & 854 & & 552 & & \\
\hline
\end{tabular}

Source: Researcher's field data.

According to the presented data, the differences were, The Daily Star cited more government officials as mentioning that the newspaper focused on the government responsibility frame. On the other hand, The Daily Kalerkantho relied more on expert sources. The Daily Kalerkantho may view COVID-19 as a medical issue, and mass people would get more suggestions with expert quotes. Compare to other dailies, The Daily Ittefaq frequently cited international sources as this paper emphasized on affected region frame to describe world scenario.

\section{Conclusion}

In Bangladesh, COVID-19 patients' numbers are increasing day by day. At this stressful time, authentic, accurate, and in-depth information will play a key role to educate, empower, and protect people from this fatal disease and its multi-dimensional consequences. Like global media, print media in Bangladesh is fully concentrating on this ongoing pandemic. Although this study depicts that The Daily Star, The Daily Kalerkantho, and The Daily Ittefaq, three prominent newspapers in Bangladesh gave more attention after the pandemic announcement on March 11, 2020, before that the coronavirus issue was not well focused. However, it would be more beneficial if they paid more concern about this fetal virus and public awareness after the WHO's Global Health Emergency declaration on January 30, 2020. This study also revealed that The Daily Star emphasized on government responsibility frame, which indicated that this daily insisted the government for taking appropriate measures to solve the difficulties linked to the outbreak.

On the other hand, the responsibility of the individual frame was highlighted by The Daily Kalerkantho, which pointed out that citizen's action is also significant to halt the diseases. Compare to others, The Daily Ittefaq concentrated on the economic consequence frame. Regarding the sources used in articles, all the newspapers mostly cited government officials as a source. In a crisis, journalist mainly relies on 'government officials' as an authentic source. This study also aligned with this hypothesis. Therefore, experts, laypeople, and international sources also got great attention. This is the first reported study on the coverage of the COVID19 pandemic in Bangladeshi newspapers. Journalism and media studies students, academicians, and journalists will be most beneficiaries of this study. The findings can be used to compare with other countries' print media coverage on the COVID-19 pandemic. Due to time limitations, this study only covered the early 
stage of COVID- 19 in Bangladesh. So more samples with an extended period might clearly illustrate the focus of print media regarding the COVID-19 pandemic.

Acknowledgment: We are grateful to Md. Nuruzzaman Khan, Ph.D. scholar (Clinical Epidemiology and Medical Statistics), The University of Newcastle, Australia, for his support in data analysis.

Funding: self-funded.

Author Contributions: conceptualization, Pryanka Dutta; data curation, Pryanka Dutta, Urme Dutta, Sanaulla Hasan, Nandita Sarkar; formal analysis, Tanmoy Sana; funding acquisition, Pryanka Dutta, Urme Dutta, Sanaulla Hasan, Nandita Sarkar, Tanmoy Sana; investigation, Pryanka Dutta, Urme Dutta, Sanaulla Hasan, Nandita Sarkar; methodology, Pryanka Dutta, Tanmoy Sana; project administration, Pryanka Dutta, Urme Dutta, Sanaulla Hasan, Nandita Sarkar, Tanmoy Sana; resources, Pryanka Dutta, Urme Dutta, Sanaulla Hasan, Nandita Sarkar, Tanmoy Sana; software, Pryanka Dutta, Urme Dutta, Sanaulla Hasan, Nandita Sarkar, Tanmoy Sana; supervision, Tanmoy Sana; validation, Pryanka Dutta, Urme Dutta, Sanaulla Hasan; visualization, Pryanka Dutta, Urme Dutta, Sanaulla Hasan, Nandita Sarkar, Tanmoy Sana; writing - original draft, Pryanka Dutta, Urme Dutta; writing - review \& editing, Tanmoy Sana.

\section{References}

1. Bardhan, N. (2001). Transnational AIDS-HIV news narratives: A critical exploration of overarching frames. Mass Communication \& Society, 4, 283-309. Available at: https://doi.org/10.1207/S15327825MCS0403 03.

2. BBC. (2020a). Coronavirus: Greatest test since World War Two, says UN chief [Online]. Available at: https://www.bbc.com/news/world-52114829 [Accessed 05/15/2020 2020].

3. BBC. (2020b). Coronavirus: Oil price collapses to lowest level for 18 years [Online]. Available at: https://www.bbc.com/news/business-52089127 [Accessed 05/15/2020 2020].

4. Beaudoin, C. E. (2007). SARS news coverage and its determinants in China and the US. International Communication Gazette, 69, 509-524. Available at: https://doi.org/10.1177/1748048507082839.

5. Bennett, W. L. (2016). News: The politics of illusion, University of Chicago Press. Available at: https://books.google.com.au/books?id=jGHNDAAAQBAJ\&dq=inauthor:\%22W.+Lance+Bennett\%22\& source=gbs_book_similarbooks.

6. Berinsky, A. J. \& Kinder, D. R. (2006). Making sense of issues through media frames: Understanding the Kosovo crisis. The Journal of Politics, 68, 640-656. Available at: https://doi.org/10.1111/j.14682508.2006.00451.x.

7. Boin, A., 'T Hart, P. \& Mcconnell, A. (2009). Crisis exploitation: political and policy impacts of framing contests. Journal of European Public Policy, 16, 81-106. Available at: https://doi.org/10.1080/13501760802453221.

8. Boseley, S. (2020). WHO urges countries to 'track and trace' every Covid-19 case. The Guardian, Sat 14 Mar 202005.13 AEDT. Available at: https://www.theguardian.com/world/2020/mar/13/who-urgescountries-to-track-and-trace-every-covid-19-case.

9. Conrad, P. (1999). Uses of expertise: Sources, quotes, and voice in the reporting of genetics in the news. Public Understanding of science, 8, 285-302. Available at: https://doi.org/10.1088/0963-6625/8/4/302.

10. De Vreese, C. H., Boomgaarden, H. G. \& Semetko, H. A. (2011). (In)direct Framing Effects: The Effects of News Media Framing on Public Support for Turkish Membership in the European Union. Communication Research, 38, 179-205. Available at: https://doi.org/10.1177/0093650210384934.

11. Entman, R. M. (1993). Framing: Toward clarification of a fractured paradigm. Journal of communication, 43, 51-58. Available at: https://doi.org/10.1111/j.1460-2466.1993.tb01304.x.

12. Entman, R. M., Matthes, J. \& Pellicano, L. (2009). Nature, sources, and effects of news framing. The handbook of journalism studies. Routledge. Available at: http://www.rasaneh.org/images/news/atachfile/30-9-1390/file634600594129473750.pdf\#page=196.

13. Gadekar, R., Krishnatray, P. \& Ang, P. H. (2014). Framing of the H1N1 Flu in an Indian Newspaper. Journal of Creative Communications, 9, 49-66. Available at: https://doi.org/10.1177/0973258613517438.

14. Gralinski, L. E. \& Menachery, V. D. (2020). Return of the Coronavirus: 2019-nCoV. Viruses, 12, 135. Available at: https://doi.org/10.3390/v12020135. 
15. Hasan, S. \& Dutta, P. (2019). Coverage of Environmental Issues in Local Dailies of Chattogram Centering World Environment Day. SocioEconomic Challenges, 3(4), 63-71. Available at: https://doi.org/10.21272/sec.3(4).63-71.2019.

16. Heymann, D. L. \& Shindo, N. (2020). COVID-19: what is next for public health? The Lancet, 395, 542545. DOI: $10.1016 / \mathrm{S} 0140-6736(20) 30374-3$.

17. Hong, T. (2007). Information control in time of crisis: The framing of SARS in China-based newspapers and Internet sources. Cyberpsychology \& behavior, 10, 696-699. Available at: https://doi.org/10.1089/cpb.2007.9968.

18. IEDCR. (2020). Institute of Epidemiology Disease Control And Research [Online]. Available at: https://www.iedcr.gov.bd/ [Accessed June 30, 2020].

19. Iyengar, S. (1991). Is anyone responsible? How television frames political issues. Chicago, IL: University of Chicago Press. Available at: https://doi.org/10.1080/08821127.1996.10731868.

20. Iyengar, S. (1996). Framing responsibility for political issues. The Annals of the American Academy of Political and Social Science, 546, 59-70. Available at: https://doi.org/10.1177/0002716296546001006.

21. JHCRC. 2020. COVID-19 map: Johns Hopkins Coronavirus Resource Center [Online]. Available at: https://coronavirus.jhu.edu/map.html [Accessed June 30, 2020].

22. Jung OH, H., Hove, T., Paek, H.-J., Lee, B., Lee, H. \& Kyu Song, S. (2012). Attention cycles and the H1N1 pandemic: A cross-national study of US and Korean newspaper coverage. Asian Journal of Communication, 22, 214-232. Available at: https://doi.org/10.1080/01292986.2011.642395.

23. Kee, C. P., Ibrahim, F. \& Mustaffa, N. (2010). Framing a pandemic: Analysis of Malaysian mainstream newspapers in the H1N1 coverage. Journal of Media and Information Warfare, 3, 105-122. Available at: https://jmiw.uitm.edu.my/images/Journal/vol3chap6.pdf.

24. Lasorsa, D. L. \& Reese, S. D. (1990). News source use in the crash of 1987: A study of four national media. Journalism Quarterly, 67, 60-71. Available at: https://doi.org/10.1177/107769909006700110.

25. Last, J. M., Harris, S. S., Thuriaux, M. C. \& Spasoff, R. A. (2001). A dictionary of epidemiology, International Epidemiological Association, Inc. Available at: http://115.78.239.30:8080/dspace/handle/DNULIB_52011/2354.

26. Lee, S. \& Paik, J. E. (2017). How partisan newspapers represented a pandemic: the case of the Middle East respiratory syndrome in South Korea. Asian Journal of Communication, 27, 82-96. Available at: https://doi.org/10.1080/01292986.2016.1235592.

27. Liu, Z., Xiao, X., Wei, X., Li, J., Yang, J., Tan, H., Zhu, J., Zhang, Q., Wu, J. \& Liu, L. (2020). Composition and divergence of coronavirus spike proteins and host ACE2 receptors predict potential intermediate hosts of SARS-CoV-2. Journal of medical virology, 92, 595-601. Available at: https://doi.org/10.1002/jmv.25726.

28. Luther, C. A. \& Zhou, X. (2005). Within the boundaries of politics: News framing of SARS in China and the United States. Journalism \& Mass Communication Quarterly, 82, 857-872. Available at: https://doi.org/10.1177/107769900508200407.

29. Mahmud, F. (2020). Coronavirus: In dense Bangladesh, social distancing a tough task. Aljazeera, March 20, 2020. Available at: https://www.aljazeera.com/news/2020/03/coronavirus-dense-bangladesh-socialdistancing-tough-task-200320103733470.html.

30. Marketwatch. (2020). The coronavirus crisis could see 37 million jobs lost, and these workers will be the hardest hit, chart shows [Online]. Available at: https://www.marketwatch.com/story/37-million-jobscould-be-lost-in-the-coronavirus-crisis-and-these-workers-will-be-the-hardest-hit-chart-shows-2020-0322 [Accessed 05/15/2020].

31. Mastin, T., Choi, J., Barboza, G. E. \& Post, L. (2007). Newspapers' framing of elder abuse: It's not a family affair. Journalism \& Mass Communication Quarterly, 84, 777-794. Available at: https://doi.org/10.1177/107769900708400408.

32. Mccombs, M. (2002). The agenda-setting role of the mass media in the shaping of public opinion. Mass Media Economics 2002 Conference, London School of Economics. Available at: http://sticerd. 1se. ac. uk/dps/extra/McCombs. pdf, 2002.

33. Mccombs, M. (2018). Setting the agenda: Mass media and public opinion, John Wiley \& Sons. Available at: https://www.wiley.com/enus/Setting+the+Agenda $\% 3 \mathrm{~A}+$ Mass+Media+and+Public+Opinion $\% 2 \mathrm{C}+2 \mathrm{nd}+$ Edition-p$\underline{9780745661094 .}$ 
34. Mogaji, E. (2020). Financial Vulnerability During a Pandemic: Insights for Coronavirus Disease (COVID-19). Mogaji, E, 57-63. Available at: http://dx.doi.org/10.2139/ssrn.3547729.

35. Molla, M. A.-M. (2020). Govt now scrambles for testing kits, PPE. The Daily Star, March 19, 2020. Available at: https://epaper.thedailystar.net/.

36. MOSTAFA, N. (2018). Critical Care Medicine: Bangladesh Perspective. Advanced journal of emergency medicine, 2. Available at: DOI: 10.22114/ajem.v0i0.79.

37. Nelson, T. E. \& Kinder, D. R. (1996). Issue frames and group-centrism in American public opinion. The Journal of Politics, 58, 1055-1078. Available at: https://doi.org/10.2307/2960149.

38. Pan, Z. \& Kosicki, G. M. (1993). Framing analysis: An approach to news discourse. Political communication, 10,55-75. Available at: Framing_Analysis-_an_approach_to_news_discourse.pdf.

39. Schudson, M. (2002). The news media as political institutions. Annual review of political science, 5, 249269. Available at: https://doi.org/10.1146/annurev.polisci.5.111201.115816.

40. Seale, C. (2003). Health and media: an overview. Sociology of health \& illness, 25, 513-531. Available at: https://doi.org/10.1111/1467-9566.t01-1-00356.

41. Semetko, H. A. \& Valkenburg, P. M. (2000). Framing European politics: A content analysis of press and television news. Journal of communication, 50, 93-109. Available at: https://doi.org/10.1111/j.14602466.2000.tb02843.x.

42. Shih, T.-J., Wijaya, R. \& Brossard, D. (2008). Media coverage of public health epidemics: Linking framing and issue attention cycle toward an integrated theory of print news coverage of epidemics. Mass Communication \& Society, 11, 141-160. Available at: https://doi.org/10.1080/15205430701668121.

43. Steele, J. E. (1995). Experts and the operational bias of television news: The case of the Persian Gulf War. Journalism \& Mass Communication Quarterly, 72, 799-812. Available at: https://doi.org/10.1177/107769909507200404.

44. Sujan, W. B. H. A. M. A. (2020). First death amid sloppy response. The Daily Star, March 19, 2020. Available at: http://epaper.thedailystar.net/.

45. Sundar, S. S. (1998). Effect of source attribution on perception of online news stories. Journalism \& Mass Communication Quarterly, 75, 55-68. Available at: https://doi.org/10.1177/107769909807500108.

46. Tanne, J. H., Hayasaki, E., Zastrow, M., Pulla, P., Smith, P. \& Rada, A. G. (2020). Covid-19: how doctors and healthcare systems are tackling coronavirus worldwide. Bmj, 368. Available at: doi: https://doi.org/10.1136/bmj.m1090.

47. The Daily Star. (2020). First coronavirus cases confirmed. The Daily Star, May 09, 2020. Available at: http://epaper.thedailystar.net/.

48. Wu, M. (2006). Framing AIDS in China: A comparative analysis of US and Chinese wire news coverage of HIV/AIDS in China. Asian Journal of Communication, 16, 251-272. Available at: https://doi.org/10.1080/01292980600857781.

49. Zhang, E. \& Fleming, K. (2005). Examination of characteristics of news media under censorship: A content analysis of selected Chinese newspapers' SARS coverage. Asian Journal of Communication, 15, 319-339. Available at: https://doi.org/10.1080/01292980500261639.

50. The Daily Star, February 01- April 10, 2020. Available at: http://epaper.thedailystar.net/.

51. The Daily Kalerkantho, February 01-April 10, 2020. Available at: https://www.kalerkantho.com/.

52. The Daily Ittefaq, February 01-April 10, 2020. Available at: https://www.ittefaq.com.bd/. 